\title{
Morphological and Patogenic Characterization of Sclerotinia sclerotiorum
}

\author{
Thais P. Zanatta ${ }^{1}$, Stela M. Kulczynski ${ }^{1}$, Caroline W. Guterres ${ }^{2}$, Daniele C. Fontana ${ }^{3}$, Daniela Meira ${ }^{4}$, \\ Eduardo L. Ceolin ${ }^{1}$, Eduardo Balem ${ }^{1}$, Mateus Trevisan ${ }^{1}$, Joao Antônio Paraginski ${ }^{1} \&$ Paola A. Buffon ${ }^{5}$ \\ ${ }^{1}$ Department of Agronomy, Federal University of Santa Maria, Frederico Westphalen, Brazil \\ ${ }^{2}$ Phytopathology Sector, Central Cooperative Gaúcha, Cruz Alta, Brazil \\ ${ }^{3}$ Plant Engineering Department, Higher Education in Agriculture Luiz De Queiroz, University of São Paulo, \\ Piracicaba, Brazil \\ ${ }^{4}$ Department of Agronomy, Federal Technological University of Parana, Pato Branco, Brazil \\ ${ }^{5}$ Plant Engineering Department, Federal University of Santa Maria, Santa Maria, Brazil \\ Correspondence: Thais P. Zanatta, Department of Agronomy, Federal University of Santa Maria, RS Campus, \\ Line 7 of September, s/n, BR 386, Km 40, Frederico Westphalen, Brazil. Tel: 55-54-999-682-026. E-mail: \\ thais_2zanatta@hotmail.com
}

Received: March 16, $2019 \quad$ Accepted: April 20, $2019 \quad$ Online Published: June 15, 2019
doi:10.5539/jas.v11n8p302
URL: https://doi.org/10.5539/jas.v11n8p302

The research is financed by CAPES.

\begin{abstract}
White mold is a disease with a wide distribution worldwide. Temperatures between $18-23{ }^{\circ} \mathrm{C}$ and high humidity conditions favor the occurrence of the pathogen. For the control of the disease it is fundamental to understand the morphology and pathogenicity of the fungus. The objective of this study was to characterize the morphological and pathogenic characteristics of Sclerotinia sclerotiorum isolates from the state of Rio Grande do Sul. Sclerodes were disinfested, placed in the center of plates containing culture medium and incubated under controlled conditions. The evaluations were performed daily, during a period of 30 days, from the incubation of sclerotia. The experimental design was completely randomized, with four plaques per isolate, each plate one replicate. The characteristics evaluated for the mycelium characterization were: time required for the fungus to occupy the plate; density of the formed mycelium; coloration of the colonies and mycelial growth rate. Scleroderma assessments were based on training or not; time for formation of the first sclerodium; total amount formed per plate; Format; distribution in the colony and weight. The isolates were pathogenically characterized by the methodology of inoculation of the detached leaf. All data were submitted to analysis of variance and the means were compared by the Skott-Knott test, at $1 \%$ probability. The evaluated populations presented wide variability for the studied characteristics. It was not possible to verify the existence of common groups that could be related to the origin of the isolates, due to the high genetic diversity. The isolates showed different levels of aggressiveness, the two being more aggressive LF02 and LF06.
\end{abstract}

Keywords: white mold, morphology, pathogenicity, control

\section{Introduction}

The white mold, caused by the fungus Sclerotinia sclerotiorum (Lib.), is a disease with worldwide distribution, infecting more than 400 species of plants, except for species of the family Poaceae (Juliatti et al., 2015). Among the most important crops attacked by the fungus are beans, soybean, cotton, sunflower, tomato and potato (Demant, 2010).

Soft temperatures, between $18-23{ }^{\circ} \mathrm{C}$ and high humidity conditions, favor the occurrence of the pathogen. With low incidence of the disease per hectare, this can occur sporadically and in small reboleiras, not causing significant losses to the cultures. However, the use of contaminated and/or infected seeds, continuous crops in monoculture, succession of crops with susceptible species or hosts, mild nocturnal temperatures (below $18^{\circ} \mathrm{C}$ ), prolonged rains during cultivation, excessive nitrogen fertilization and uncontrolled irrigation of the amount of 
water supplied (Leite, 2005; Juliatti \& Juliatti, 2010; Silva et al., 2010) cause white mold to spread, assuming great economic and social importance.

Due to the abundant production of sclerotia, which allow for the survival of the fungus in the soil for more than 10 years, white-mold is considered a disease of difficult control (Reis \& Tomazini, 2005). For the good control of diseases it is essential to understand the etiology, morphology and pathogenicity of pathogens (Kohli et al., 2003). There is still relatively little information on the etiology, pathogenicity and morphology of $S$. sclerotiorum in the literature, especially for Southern Brazil.

The variability of $S$. sclerotiorum isolates was reported in several studies. In 1930, Dickson studied 33 isolates and found a difference between the density of mycelium, which varied from air to air, and in mycelial growth rates. Morral et al. (1972) studied 114 isolates of S. sclerotiorum from 23 hosts collected in Canada and found variations in colony color, mycelial growth rate and abundance, and size, shape and size of sclerotia. Corradini (1989) observed large variability in the growth and diameter of colonies, type and color of mycelium, production, weight and distribution of sclerotia, and in the production of apotécios in 19 isolates from the Alto Paranaíba-MG region.

According to Pariuad et al. (2009), it is possible to evaluate the aggressiveness of the isolates of different forms, either by the infection efficiency, by the latent period, by the spore production rate and by the size of the lesion. Lehner et al. (2015) compared the aggressiveness of $20 \mathrm{~S}$. sclerotiorum isolates and determined the relationship between aggressiveness and variability. According to the authors, similar levels of aggressiveness were observed among the isolates collected in four Brazilian states. However, there was no relationship between aggressiveness and morphological characteristics of mycelial pigmentation, growth rate and sclerotia production.

The present work had as objective to perform the survey, the morphological and pathogenic characterization of $S$. sclerotiorum isolates obtained from commercial production fields in the state of Rio Grande do Sul.

\section{Material and Methods}

The experiments were carried out at the Phytopathology Laboratory of the Federal University of Santa Maria, Frederico Westphalen/RS.

\subsection{Obtaining the Isolates}

Isolates of S. sclerotiorum were collected in 20 different contaminated commercial production fields in the state of Rio Grande do Sul. After collection, samples were stored in paper bags (room temperature) and sent to Laboratory of Phytopathology of UFSM, Frederico Westphalen/RS. The identification of the isolates, the cultures from which they were collected, the municipalities of collection, the collectors and the year of collection of each isolate are specified in Table 1. 
Table 1. Characterization of the isolates according to the cultures from which they were collected, the municipalities of collection, the collectors and the year of collection of each S. sclerotiorum isolate used in the experiments. Frederico Westphalen, RS, 2018

\begin{tabular}{|c|c|c|c|c|}
\hline Isolated Code & Collection culture & Cities of collection & Collector & Year \\
\hline LF01 & Soybean (Glycine max L.) & Rio Grande & Cristiano Bellé (UFPel) & $2017 *$ \\
\hline LF02 & Soybean (Glycine $\max \mathrm{L})$. & Bagé & Cristiano Bellé (UFPel) & $2017 *$ \\
\hline LF03 & Soybean (Glycine $\max \mathrm{L})$. & Boa Vista das Missões & Cristiano Bellé (UFPel) & $2017 *$ \\
\hline LF04 & Soybean (Glycine $\max$ L.) & Itaqui & Cristiano Bellé (UFPel) & $2017 *$ \\
\hline LF05 & Soybean (Glycine max L.) & Pelotas & Cristiano Bellé (UFPel) & $2017 *$ \\
\hline LF06 & Soybean (Glycine $\max$ L.) & Cristal & Cristiano Bellé (UFPel) & $2017 *$ \\
\hline LF07 & Soybean (Glycine max L.) & Seberi & Cristiano Bellé (UFPel) & $2017 *$ \\
\hline LF08 & Soybean (Glycine max L.) & Turuçu & Cristiano Bellé (UFPel) & $2017 *$ \\
\hline LF09 & Canola (Brassica napus L.) & Giruá & Cristiano Bellé (UFPel) & $2017 *$ \\
\hline LF10 & Soybean (Glycine max L.) & Palmeira das Missões & Carla Janaína Werner (Sementes Dallazen) & 2017 \\
\hline LF11 & Nabo (Brassica rapa L.) & Cruz Alta & Nelson Neto (UNICRUZ) & $2017 *$ \\
\hline LF12 & Soybean (Glycine max L.) & Tapera & Anderson Moresco (UPL) & 2017 \\
\hline LF13 & Soybean (Glycine $\max$ L.) & Passo Fundo & Carolina Deuner (UPF) & $2017 *$ \\
\hline LF14 & Lettuce (Lactuca sativa L.) & Santa Maria & UFSM & $2017 *$ \\
\hline LF15 & Soybean (Glycine $\max \mathrm{L})$. & São Lourenço do Sul & Cristiano Bellé (UFPel) & $2017 *$ \\
\hline LF16 & Soybean (Glycine max L.) & Água Santa & Alexandre Nicola (UNIAGRO) & 2017 \\
\hline LF17 & Soybean (Glycine $\max$ L.) & Santo Augusto & Willian Araldi (DUPONT) & 2017 \\
\hline LF18 & Soybean (Glycine $\max \mathrm{L})$. & Frederico Westphalen & Bruno Schneider (UFSM) & 2017 \\
\hline LF19 & Soybean (Glycine max L.) & Vacaria & Carolina Deuner (UPF) & $2017 *$ \\
\hline LF20 & Soybean (Glycine $\max$ L.) & Sarandi & Thais Pollon Zanatta & 2017 \\
\hline
\end{tabular}

Note. * Year in which the isolates were sent.
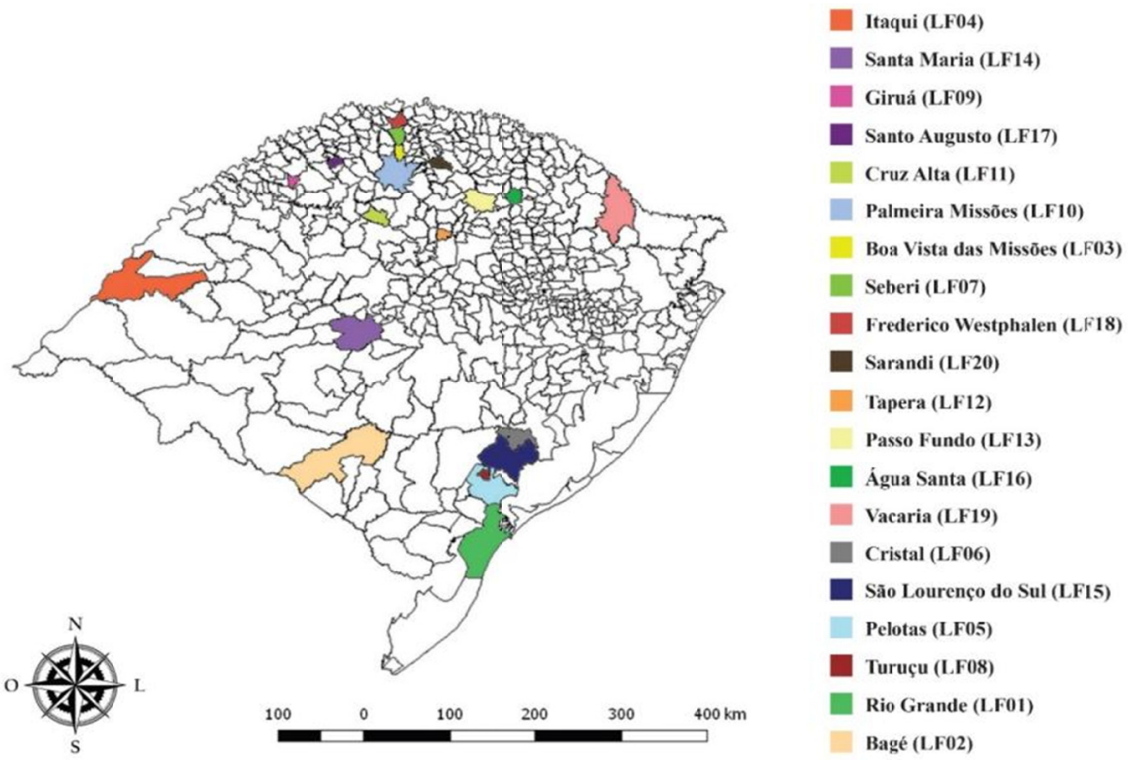

Figure 1. Cities of origin of S. sclerotiorum isolates, according to map of Rio Grande do Sul. Frederico Westphalen, RS, 2018

To perform the morphological and physiological characterization evaluations of each isolate, the sclerodes were first superficially disinfested with $70 \%$ alcohol and $1 \%$ sodium hypochlorite, both for 1 minute. Afterwards, they were rinsed in distilled and sterilized water. Sclerodes were placed in the center of Petri dishes containing potato-dextrose-agar medium (BDA) and incubated in BOD under controlled conditions of temperature $\left(18 \pm 2{ }^{\circ} \mathrm{C}\right)$ and photoperiod (12 hours). 


\subsection{Morphological Characterization of S. sclerotiorum Isolates}

The characterization of the isolates of $S$. sclerotiorum were based on the development parameters and morphological aspect of the fungus in the BDA.

The assay setup was performed with the sclerotia inoculation in Petri dishes containing BDA culture medium. Initially the sclerodes obtained were disinfested according to item 2.1. Evaluations were performed daily over a period of 30 days from the incubation of the sclerotia on the plates. The experimental design was completely randomized, with four replicates and the experimental unit composed of a Petri dish.

\subsection{Mycelial Characterization of the Colonies}

The characteristics evaluated for the characterization of the mycelium were: time required for the fungus to occupy the Petri dish $(90 \mathrm{~mm})$, evaluated daily until the fungus reaches the border of Petri dish; density of the mycelium formed, evaluated at 30 days after inoculation, classified in 3 categories, being A-abundant (when a thick and uniform layer of mycelium formed on the medium), R-drainage (when only a thin and homogeneous layer developed on the medium) or I-irregular (when there was no pattern of mycelium formation on the medium or between the plates of the same isolate); colonies, evaluated at 30 days after inoculation, classified in 4 categories, being BR-white, BE-beige, MA-brown or PE-black (Chaves, 1961; Corradini, 1989).

\subsection{Mycelial Growth Rate}

Daily evaluations of mycelial growth were performed by measurements $(\mathrm{cm})$ of the radial growth of the colony on two orthogonal axes, and then averaged, for later determination of mycelial growth rate (MCV) and mycelial growth rate index (IVCM).

The VCM was determined by dividing the final growth measure by the number of days the pathogen took to grow, with results expressed in mm day-1. For the IVCM variable, four intervals were analyzed: $0-24,24-48$, 48-72 and 72-96 hours of incubation and after calculation, using the adapted Oliveira (1991) formula:

$$
\mathrm{IVCM}=\frac{\sum(\mathrm{D}-\mathrm{Da})}{\mathrm{N}}
$$

where, $\mathrm{IVCM}=$ rate of growth rate; $\mathrm{D}=$ current mean diameter of the colony; $\mathrm{Da}=$ mean diameter of the colony the day before; $\mathrm{N}=$ number of days after inoculation.

\subsection{Characterization of Sclerodes Produced}

The characteristics evaluated for the characterization of the sclerotia were: formation or not of sclerotia; time to form the first sclerodium (days), being considered as sclerodium formed what reached the third stage of genesis, which is known as maturation, occurs surface delimitation, deposition of peripheral cells rich in melanin and consolidation of the internal marrow (Townsend \& Wilts, 1954); total amount of sclerodes formed (counted at 30 days after incubation); form of the sclerodes, being AR-rounded, IR-irregular and DI-diverse; distribution of sclerotia in the colony, classified as: AU-absent, DC-dispersed in colony, RPM-regular near margin, in CC-concentric circles and in C-center; (s) after being removed from the plates and dried at room temperature for $48 \mathrm{~h}$ (Chaves, 1961; Corradini, 1989).

\subsection{Pathogenic Characterization of S. sclerotiorum Isolates Using the Detached Leaf Method}

After the morphological characterization, the isolates were characterized pathogenically by the methodology of inoculation of the highlighted leaf (Garcia, 2008). For this, soybean seeds of the cultivar BMX Lança IPRO were sown in $3 \mathrm{~L}$ pots containing sterilized substrate under greenhouse conditions. When the plants reached phenological stage V4 (fourth node) (Fehr \& Caviness, 1977), the tripholes were detached from the mother plant with scissors and placed in sterile plastic boxes containing five glass slides and two sheets of filter paper previously wet with distilled and sterilized water.

The choice of the grow crops BMX Lança IPRO was due to the fact that it is widely used by farmers in Rio Grande do Sul and is presenting a high susceptibility to white mold.

The isolates were inoculated by placing a 5 day old BDA disc with the fungus culture on the center of the leaflet of the soybean leaf, with the mycelium of the fungus in direct contact with the surface of the leaf. After inoculation, the leaflets were kept at $20 \pm 2{ }^{\circ} \mathrm{C}$ and photoperiod for 12 hours. Four leaflets were inoculated and evaluated per isolate. The experimental design was completely randomized, with four replicates and the experimental unit composed of a gerbox type box. 
The disease severity assessments (sick leaf area) started 24 hours after inoculation, based on a diagrammatic scale (Garcia \& Juliatti, 2008) (Figure 2), extending up to the 120-hour period after inoculation, taking a 24-hour interval between evaluations.

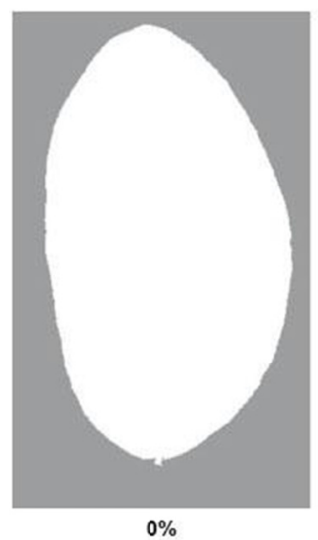

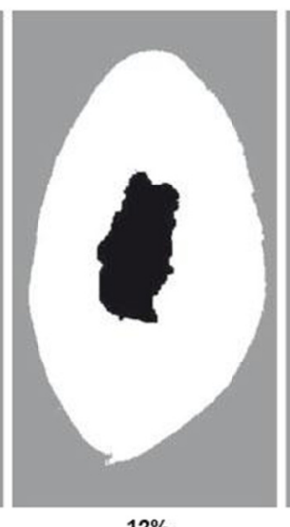

$12 \%$

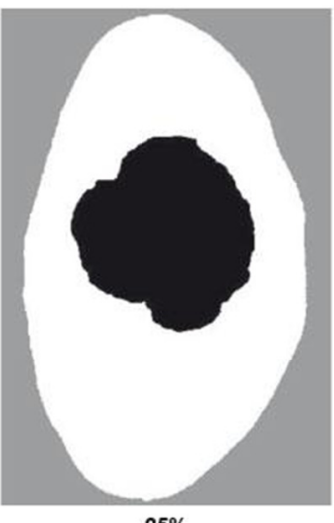

$25 \%$

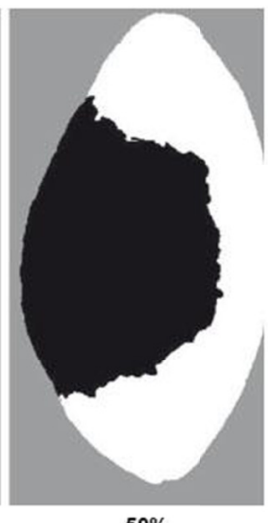

$50 \%$

Figure 2. Diagrammatic scale of symptoms of S. sclerotiorum in soybean leaflets (Glycine max) (GARCIA, 2008), Frederico Westphalen, RS, 2018

The values of the area under the disease progress curve (AACPD) were calculated for each isolate by the following equation (Shaner \& Finney, 1977):

$$
\operatorname{AACPD}=\sum_{\mathrm{i}=1}^{\mathrm{n}}\left(\frac{\mathrm{Y}_{\mathrm{i}+1}+\mathrm{Y}_{\mathrm{i}}}{2}\right) \times\left(\mathrm{T}_{\mathrm{i}+1}-\mathrm{T}_{\mathrm{i}}\right)
$$

where, n: number of observations; Yi: disease severity on the " $\mathrm{i}$ "-th observation; Ti: time in days in the "i"-th observation.

\subsection{Statistical Analysis}

All data were submitted to analysis of variance and the means were compared by the Skott-Knott test, $1 \%$ probability, by the SISVAR statistical program (Ferreira, 2000).

\section{Results and Discussion}

\subsection{Morphological Characterization of S. sclerotiorum Isolates}

The analysis of variance showed a significant difference between the 20 isolates of $S$. sclerotiorum for the variables referring to the morphological characterization. The Scott-Knott averages test $(p<0.1)$ separated the isolates into 10 distinct groups according to the mycelial growth rate index (IVCM) and showed a coefficient of variation of $4.2 \%$ (Table 2 ).

The slower growing isolate was LF19 (Vacaria City, soybean culture), which presented a mean growth of 4.57 $\mathrm{mm}$ day $^{-1}$, with IVCM of 18.27. The highest growth isolate was LF08 (Turuçu City, soybean culture) presented a mean growth of $13.73 \mathrm{~mm} \mathrm{day}^{-1}$, with IVCM of 54.91 (Table 2). Of the isolates, $20 \%$ presented daily growth of mycelium between 10.08 and 10.48 (Table 2). 
Table 2. Mycelial growth rate (VCM), mycelial growth rate index (IVCM), number and percentage of isolates of Sclerotinia sclerotiorum. Frederico Westphalen, RS, 2018

\begin{tabular}{lllll}
\hline Group Scott Knott & VCM $\left(\mathbf{m m ~ d a y ~}^{-\mathbf{1}}\right)$ & IVCM & $\mathbf{N}^{\mathbf{0}}$ Isolated & \% Isolated \\
\hline A & 13.73 & 54.91 & 1 & 5 \\
B & $12.710-12.262$ & $50.84-53.05$ & 3 & 15 \\
C & $11.77-12.20$ & $47.09-48.80$ & 3 & 15 \\
D & $11.19-11.47$ & $44.76-45.88$ & 2 & 10 \\
E & 10.67 & 42.74 & 1 & 5 \\
F & $10.08-10.48$ & $40.33-41.94$ & 4 & 20 \\
G & 9.24 & 36.97 & 1 & 5 \\
H & 7.12 & 28.5 & 1 & 5 \\
I & $6.27-6.46$ & $25.10-25.86$ & 3 & 15 \\
J & 4.57 & 18.27 & 1 & 5 \\
\hdashline $\mathbf{C V}(\%)$ & 3.9 & 4.2 & & \\
\hline
\end{tabular}

All the evaluated isolates completed the petri dishes with mycelium about 96 hours after incubation, corroborating with data from Corradini (1989), who evaluated 19 S. sclerotiorum isolates and observed that the colonies reached the maximum diameter of the plaque at the end of 120 hours of incubation.

The mycelial growth velocities found in this work ranged from 13.73 to $6.09 \mathrm{~mm} \mathrm{dia}^{-1}$. These values are below those found by Abreu (2011), where two slower isolates (UFLA 20 and UFLA 23) had a mean growth of 14.75 mm day ${ }^{-1}$.

For the variable type of mycelium produced, $20 \%$ of the isolates presented abundant mycelium and $30 \%$ irregular mycelium, that is, there was no pattern of mycelium formation in the plates. Half of the isolates (50\%) showed thin mycelial growth, characterized by a thin layer of mycelium covering the surface of the plaque (Figure 3). Similar data were obtained by Grabicoski (2012) when evaluating 57 isolates of S. sclerotiorum. It classified the mycelium in 3 types, being predominant the mycelium of the irregular type. Corradini (1989) also obtained similar results, where $50 \%$ of the isolates presented mycelium thin.
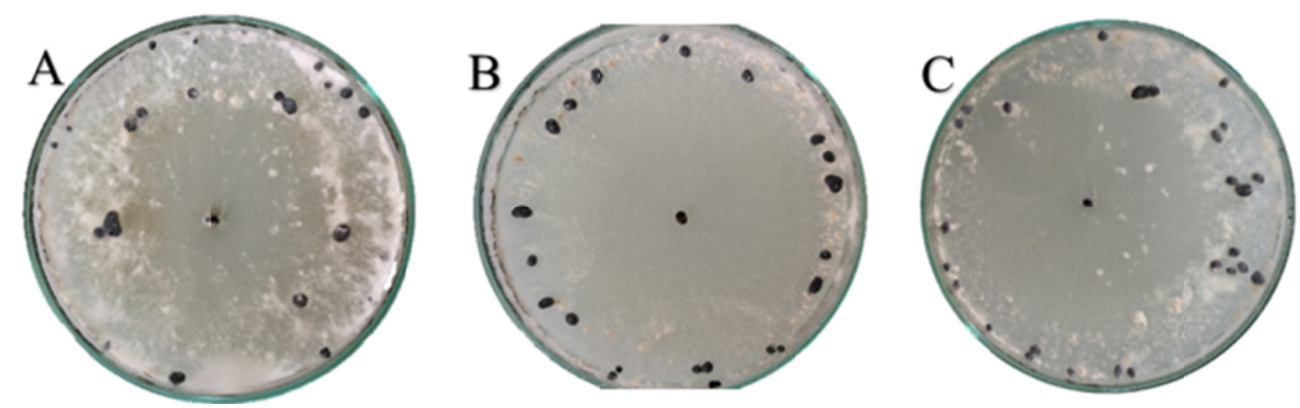

Figure 3. Predominant mycelium types in colonies of $S$. sclerotiorum in BDA culture medium, after 30 days of incubation, being: A: abundant, B: scarce and C: irregular. Frederico Westphalen, RS, 2018

As to the predominant coloration in the colonies developed on the BDA medium, the isolates were characterized in two distinct categories, with white (BR) and beige (BE) coloration (Figure 4). Of the 20 isolates evaluated, $70 \%$ (14 isolates) presented beige coloration (Figure 4), corroborating with the results found by Abreu (2011), where most of the isolates presented predominantly beige coloration (58\%). The opposite was found by Corradini (1989), Grabicoski (2012) and Purdy (1955), who verified predominance of white mycelium in $S$. sclerotiorum isolates cultured in BDA medium. 

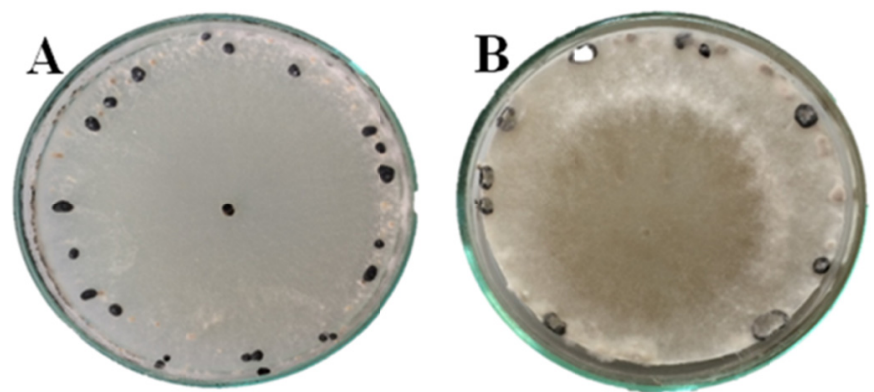

Figure 4. Predominant staining in S. sclerotiorum colonies in BDA culture medium, after 30 days of incubation, being: A: white and B: beige. Frederico Westphalen, RS, 2018

All the isolates analyzed presented sclerotia production. The distribution was $60 \%$ of the sclerodes found were regular near the margin of the plaque, $25 \%$ were scattered in the colony and $15 \%$ were in concentric circles (Figure 5).
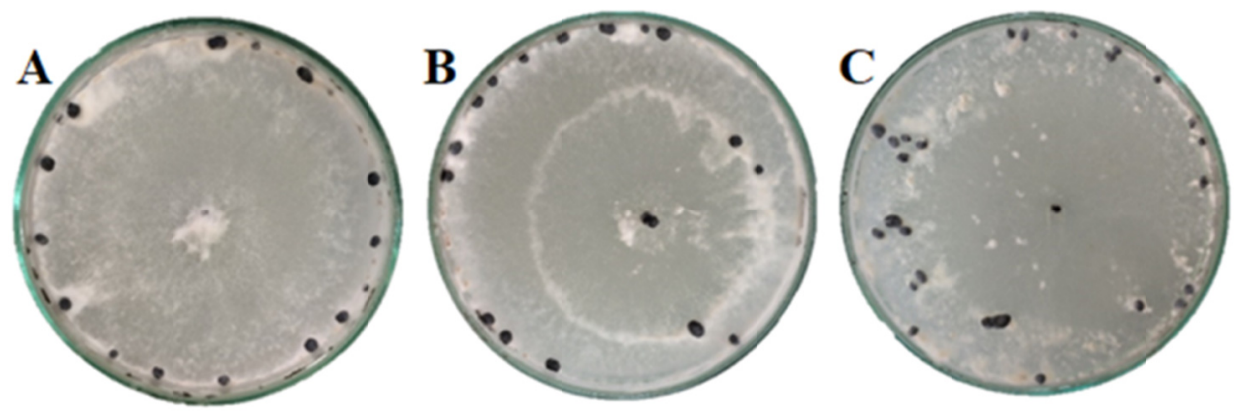

Figure 5. Distribution of sclerotia on the plate of $S$. sclerotiorum colonies in BDA culture medium, after 30 days of incubation, being: A: regular near the border of the plaque, B: concentric circles and C: dispersed in the colony. Frederico Westphalen, RS, 2018

Regarding the time required for the formation of the first sclerotia of each isolate, the analysis of variance showed that there was a significant difference between the isolates. The Scott Knott averages test $(p<0.01)$ separated the isolates into three distinct groups, with a coefficient of variation of $8.38 \%$ (Table 4). The time for sclerotia formation varied from 10.67 days with LF02 isolates (City of Bagé, soybean culture) and LF11 (City of Cruz Alta, turnip culture), up to 18 days, with LF08 isolate (City of Turuçu, soybean crop) (Table 4).

Similar data were found by Grabicoski (2012), and the mean time for sclerotia formation ranged from 11.8 to 15.4 days. For Abreu (2011), the time for formation of sclerodium in the isolates evaluated ranged from 4 to 12.44 days. Researches have not yet been able to determine the average time for the formation of sclerotia and whether training time influences their aggressiveness.

The number of sclerotia per plaque ranged from 9.67 sclerodes to the isolate LF13 (Passo Fundo City, soybean culture) to 28.17 for the isolate LF09 (Giruá City, soybean culture), presenting a significant difference between the isolates, separating the isolates in four distinct groups by the Scott Knott averages test $(\mathrm{p}<0.01)$, (Table 3). The data found in the study presented variability, corroborating with studies developed by Abreu (2011), and the number of sclerodes ranged from 10.33 to 46, and by Grabicoski (2012), ranging from 16.6 to 57.2 sclerotia per However, the present study had a lower production of sclerotia.

The mean weight of sclerotia per plaque varied from $0.0825 \mathrm{~g}$ for LF11 isolate (Cruz Alta City, turnip culture) to $0.2368 \mathrm{~g}$ for LF06 isolate (Cristal City, soybean culture). The analysis of variance of the individual mean weights of sclerodes showed that there was a significant difference between them, separating into four distinct groups according to their weight in grams, presenting a coefficient of variation of $22.18 \%$ (Table 3 ). 
Table 3. Total number of sclerotia, time to formation and mean weight of sclerotia of S. sclerotiorum isolates. Frederico Westphalen, RS, 2018

\begin{tabular}{|c|c|c|c|}
\hline \multirow{2}{*}{ Code Isolates } & \multicolumn{3}{|c|}{ Sclerotia } \\
\hline & Total Number ${ }^{1}$ & Time for Training $^{2}$ & Average Weight ${ }^{3}$ \\
\hline LF01 & $20.83 \mathrm{~b}$ & $11.33 \mathrm{c}$ & $0.1766 \mathrm{~b}^{*}$ \\
\hline LF02 & $13.33 \mathrm{~d}$ & $10.67 \mathrm{c}$ & $0.1297 \mathrm{c}$ \\
\hline LF03 & $19.00 \mathrm{c}$ & $15.17 \mathrm{~b}$ & $0.1719 \mathrm{~b}$ \\
\hline LF04 & $22.17 \mathrm{~b}$ & $10.83 \mathrm{c}$ & $0.2116 \mathrm{a}$ \\
\hline LF05 & $21.83 \mathrm{~b}$ & $14.33 \mathrm{c}$ & $0.2224 \mathrm{a}$ \\
\hline LF06 & $11.17 \mathrm{~d}$ & $11.67 \mathrm{c}$ & $0.2368 \mathrm{a}$ \\
\hline LF07 & $23.67 \mathrm{~b}$ & $10.50 \mathrm{c}$ & $0.1800 \mathrm{~b}$ \\
\hline LF08 & $22.67 \mathrm{~b}$ & $18.00 \mathrm{a}$ & $0.1766 \mathrm{~b}$ \\
\hline LF09 & $28.17 \mathrm{a}$ & $11.17 \mathrm{c}$ & $0.1846 \mathrm{~b}$ \\
\hline LF10 & $17.00 \mathrm{c}$ & $11.50 \mathrm{c}$ & $0.1808 \mathrm{~b}$ \\
\hline LF11 & $16.33 \mathrm{c}$ & $10.67 \mathrm{c}$ & $0.0825 \mathrm{~d}$ \\
\hline LF12 & $17.50 \mathrm{c}$ & $11.00 \mathrm{c}$ & $0.1543 \mathrm{c}$ \\
\hline LF13 & $9.67 \mathrm{~d}$ & $11.67 \mathrm{c}$ & $0.1425 \mathrm{c}$ \\
\hline LF14 & $19.00 \mathrm{c}$ & $14.83 \mathrm{~b}$ & $0.1066 \mathrm{~d}$ \\
\hline LF15 & $11.33 \mathrm{~d}$ & $11.50 \mathrm{c}$ & $0.1149 \mathrm{~d}$ \\
\hline LF16 & $13.33 \mathrm{~d}$ & $11.67 \mathrm{c}$ & $0.1552 \mathrm{c}$ \\
\hline LF17 & $17.83 \mathrm{c}$ & $11.17 \mathrm{c}$ & $0.1260 \mathrm{c}$ \\
\hline LF18 & $17.33 \mathrm{c}$ & $11.17 \mathrm{c}$ & $0.1541 \mathrm{c}$ \\
\hline LF19 & $16.83 \mathrm{c}$ & $11.00 \mathrm{c}$ & $0.1348 \mathrm{c}$ \\
\hline LF20 & $11.33 \mathrm{~d}$ & $11.50 \mathrm{c}$ & $0.1514 \mathrm{c}$ \\
\hline C.V. $(\%)$ & 19.27 & 8.38 & 22.18 \\
\hline
\end{tabular}

Note. * Result of the Scott Knott averages comparison test, where averages followed by the same letter in the column did not differ from each other at $1 \%$ probability.

${ }^{1}$ Number of sclerotia formed per plaque, after 30 days of incubation; ${ }^{2}$ Time required for formation of the first sclerodium plaque, in days; ${ }^{3}$ Mean weight of sclerodes, in $\mathrm{g}$.
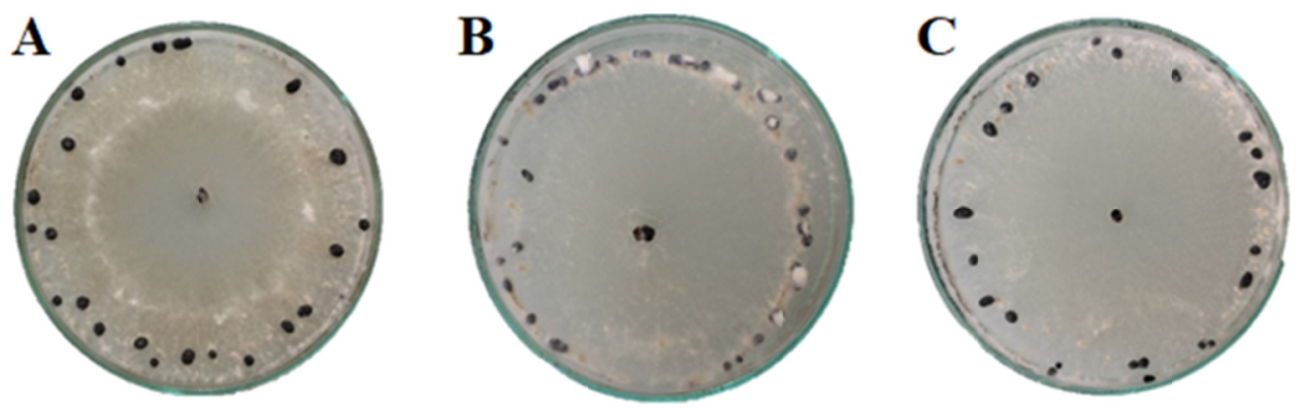

Figure 6. Format of the sclerotia formed on the plaques of S. sclerotiorum colonies in BDA culture medium, after 30 days of incubation, being: A: rounded shape, B: irregular shape and C: diverse format. FredericO Westphalen, RS, 2018

As to the shape of the sclerodes formed, $25 \%$ of the isolates presented a rounded shape (five isolates), $30 \%$ irregular shape (six isolates) and $45 \%$ presented different format (nine isolates). This variation in the shape of sclerotia can be visualized in figure 6. These data corroborate those of Kreyci (2016) who verified a large part of the sclerodes (75.3\%), with a rounded shape. However, they differ from Grabicoski (2012), which classified most isolates $(65 \%)$ as diverse, with varied formats.

Differences in mycelial growth rates and variation in color and type of mycelium can be attributed to the genetic variability among the isolates (Corradini, 1989; Grabicoski, 2012; Purdy, 1955). In a similar study, Chaves (1961) evaluated the morphological characteristics of different $S$. sclerotiorum isolates and observed that they 
differed in their speed of mycelial growth, formation velocity, amount and size of sclerodes, suggesting the possibility of genetic diversity among isolates.

However, the initial state of the sclerodes used in the evaluations may have influenced the morphological characteristics found, since while in the field, they were subject to several environmental interferences (Grabicoski, 2012). Some differences between the growth velocity, sclerotic formation and morphological characteristics among the isolates can be explained by several factors, such as age (Bueno et al., 2006), soil depth (sclerotia in the range of 5 to $20 \mathrm{~cm}$ of the surface present a longer survival time) (Akai, 1981; Saharan \& Mehta, 2008); the degree and the frequency of drought, since they do not have control over their loss of water in the event of flooding followed by drought, causing the loss of several nutrients, and thus decreasing their reserves (Willets \& Wong, 1980). These factors may contribute to reduced in vitro growth.

\subsection{Pathogenic Characterization of S. sclerotiorum Isolates}

All the isolates evaluated had lesions on the soybean leaflets. Table 4 presents the results of the evaluations every 24 hours, from 48 hours after inoculation (HAI) of the soybean leaflets with the different isolates of $S$. sclerotiorum.

Table 4. Severity at 48, 72, 96 and 120 hours after inoculation (HAI) through Garcia scale (2008) according to inoculation of different $S$. sclerotiorum isolates in soybean leaflets. FredericO Westphalen, RS, 2018

\begin{tabular}{|c|c|c|c|c|}
\hline \multirow{2}{*}{ Code Isolates } & \multicolumn{4}{|c|}{ Severity } \\
\hline & 48 HAI & 72 HAI & 96 HAI & 120 HAI \\
\hline LF01 & $1.67 \mathrm{~d}^{*}$ & $8.33 \mathrm{~d}$ & $23.83 \mathrm{c}$ & $37.83 \mathrm{c}$ \\
\hline LF02 & $49.83 \mathrm{a}$ & $61.67 \mathrm{a}$ & $80.83 \mathrm{a}$ & $97.50 \mathrm{a}$ \\
\hline LF03 & $2.50 \mathrm{~d}$ & $9.17 \mathrm{~d}$ & $15.17 \mathrm{c}$ & $23.33 \mathrm{c}$ \\
\hline LF04 & $16.17 \mathrm{c}$ & $20.00 \mathrm{c}$ & $27.50 \mathrm{c}$ & $35.00 \mathrm{c}$ \\
\hline LF05 & $13.00 \mathrm{c}$ & $19.17 \mathrm{c}$ & $41.17 \mathrm{~b}$ & $74.17 \mathrm{a}$ \\
\hline LF06 & $40.33 \mathrm{a}$ & $55.83 \mathrm{a}$ & $71.33 \mathrm{a}$ & $88.33 \mathrm{a}$ \\
\hline LF07 & $20.00 \mathrm{c}$ & $26.67 \mathrm{c}$ & $42.50 \mathrm{~b}$ & $50.00 \mathrm{~b}$ \\
\hline LF08 & $4.67 \mathrm{~d}$ & $7.50 \mathrm{~d}$ & $14.17 \mathrm{c}$ & $24.17 \mathrm{c}$ \\
\hline LF09 & $10.00 \mathrm{c}$ & $17.50 \mathrm{c}$ & $40.83 \mathrm{~b}$ & $50.00 \mathrm{~b}$ \\
\hline LF10 & $35.17 \mathrm{~b}$ & $39.17 \mathrm{~b}$ & $60.00 \mathrm{a}$ & $85.00 \mathrm{a}$ \\
\hline LF11 & $0.00 \mathrm{~d}$ & $4.17 \mathrm{~d}$ & $4.17 \mathrm{~d}$ & $5.83 \mathrm{~d}$ \\
\hline LF12 & $0.00 \mathrm{~d}$ & $1.67 \mathrm{~d}$ & $2.50 \mathrm{~d}$ & $2.50 \mathrm{~d}$ \\
\hline LF13 & $0.00 \mathrm{~d}$ & $1.50 \mathrm{~d}$ & $1.50 \mathrm{~d}$ & $2.33 \mathrm{~d}$ \\
\hline LF14 & $40.33 \mathrm{a}$ & $50.83 \mathrm{a}$ & $65.00 \mathrm{a}$ & $74.17 \mathrm{a}$ \\
\hline LF15 & $0.00 \mathrm{~d}$ & $0.00 \mathrm{~d}$ & $0.00 \mathrm{~d}$ & $0.83 \mathrm{~d}$ \\
\hline LF16 & $28.50 \mathrm{~b}$ & $36.67 \mathrm{~b}$ & $55.83 \mathrm{~b}$ & $65.83 \mathrm{~b}$ \\
\hline LF17 & $12.00 \mathrm{c}$ & $17.17 \mathrm{c}$ & $23.33 \mathrm{c}$ & $30.83 \mathrm{c}$ \\
\hline LF18 & $11.17 \mathrm{c}$ & $16.17 \mathrm{c}$ & $33.33 \mathrm{c}$ & $51.67 \mathrm{~b}$ \\
\hline LF19 & $0.00 \mathrm{~d}$ & $0.00 \mathrm{~d}$ & $0.00 \mathrm{~d}$ & $0.83 \mathrm{~d}$ \\
\hline LF20 & $24.33 \mathrm{~b}$ & $31.67 \mathrm{~b}$ & $51.67 \mathrm{~b}$ & $65.83 \mathrm{~b}$ \\
\hline CV $(\%)$ & 83.4 & 69.63 & 63.36 & 58.32 \\
\hline
\end{tabular}

Note. * Averages followed by the same letters in the column did not differ statistically from one another according to the Scott-Knott test at $1 \%$ probability.

From the analysis of variance performed, it was possible to observe significant differences between the mean scores of the lesions formed by the isolates inoculated in soybean leaflets. In the $48 \mathrm{HAI}$, the scores varied from 49.83 for isolate LF02 (Bagé City, soybean culture) to 0.00 for the isolates LF11 (Cruz Alta city, turnip culture), LF12 (Tapera city, soybean crop), LF13 (Passo Fundo city, soybean culture), LF15 (São Lourenço do Sul city, soybean culture), LF19 (Vacaria city, soybean culture). Other leaflets were practically without lesions, as in the case of leaflets inoculated with the isolates LF15 (São Lourenço do Sul city, soybean culture) and LF19 (Vacaria city, soybean culture), evidencing differences in the aggressiveness potential of the isolates studied (Table 4). 
In $120 \mathrm{HAI}$, it was possible to separate the isolates into four distinct groups of aggressiveness, each level being composed of five isolates. Level A, considered more aggressive, presented lesions ranging from 74.17 to 97.50 $\mathrm{mm}$. Level B presented lesions varying from 50 to $65.83 \mathrm{~mm}$, level C presented lesions ranging from 23.33 to 35 $\mathrm{mm}$ and level $\mathrm{D}$, considered the least aggressive, presented lesions varying from 0.83 to $5.83 \mathrm{~mm}$ (Table 4).

Figure 7 shows the differences in the size of the lesions formed in soybean leaflets, according to the four levels of aggressiveness found.
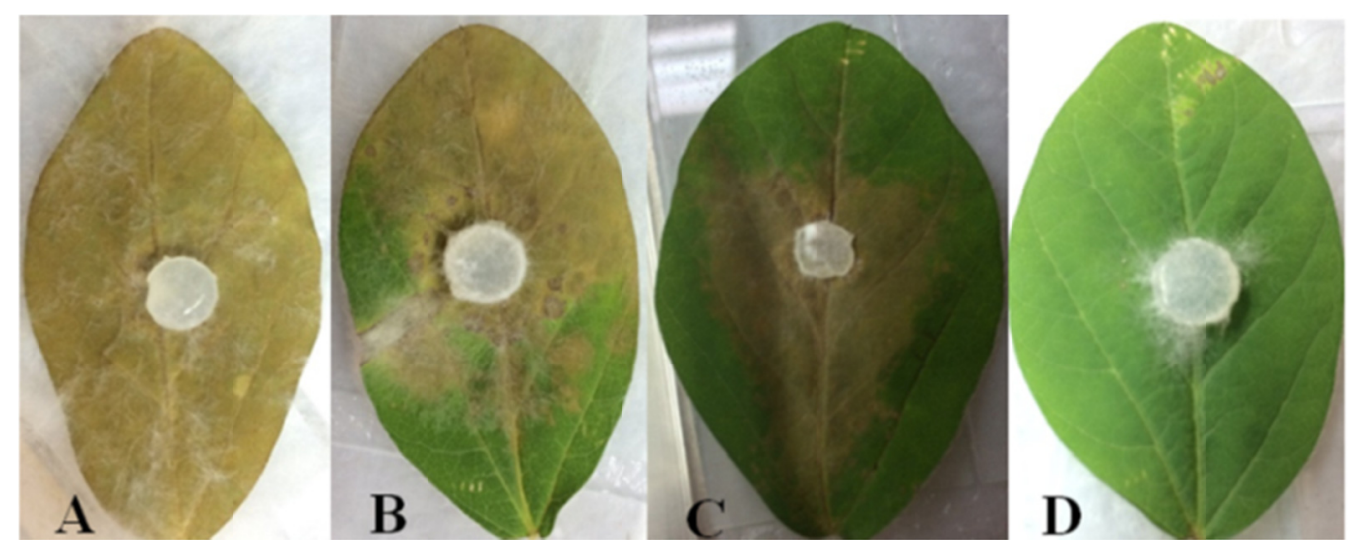

Figure 7. Comparison between different levels of aggressiveness, according to the lesion formed in soybean leaflets, after 120 hours of inoculation. Frederico Westphalen, RS, 2018

Figure 8 shows the AACPD of the isolates from different municipalities of the state of Rio Grande do Sul inoculated in soybean leaflets. It was observed that the isolates LF02 (Bagé City, soybean culture), LF06 (Cristal City, soybean culture), LF14 (Santa Maria city, lettuce culture) and LF10 (Palmeira das Missões city, soybean culture) appear to be more aggressive for the soybean. The most aggressive isolates LF03 (Boa Vista das Missões city, soybean culture), LF08 (Turuçu city, soybean culture), LF11 (Cruz Alta city, culture turnip), LF12 (Tapera city, soybean culture), LF13 (Passo Fundo city, soybean culture), LF15 (São Lourenço do Sul city, soybean culture) and LF19 (Vacaria city, soybean culture). In the present study, it was found that soybean (Kull et al., 2004), canola (Kohli et al., 1995) and sunflower (Ekins et al., 2011) differ in the aggressiveness of isolates., 1983).

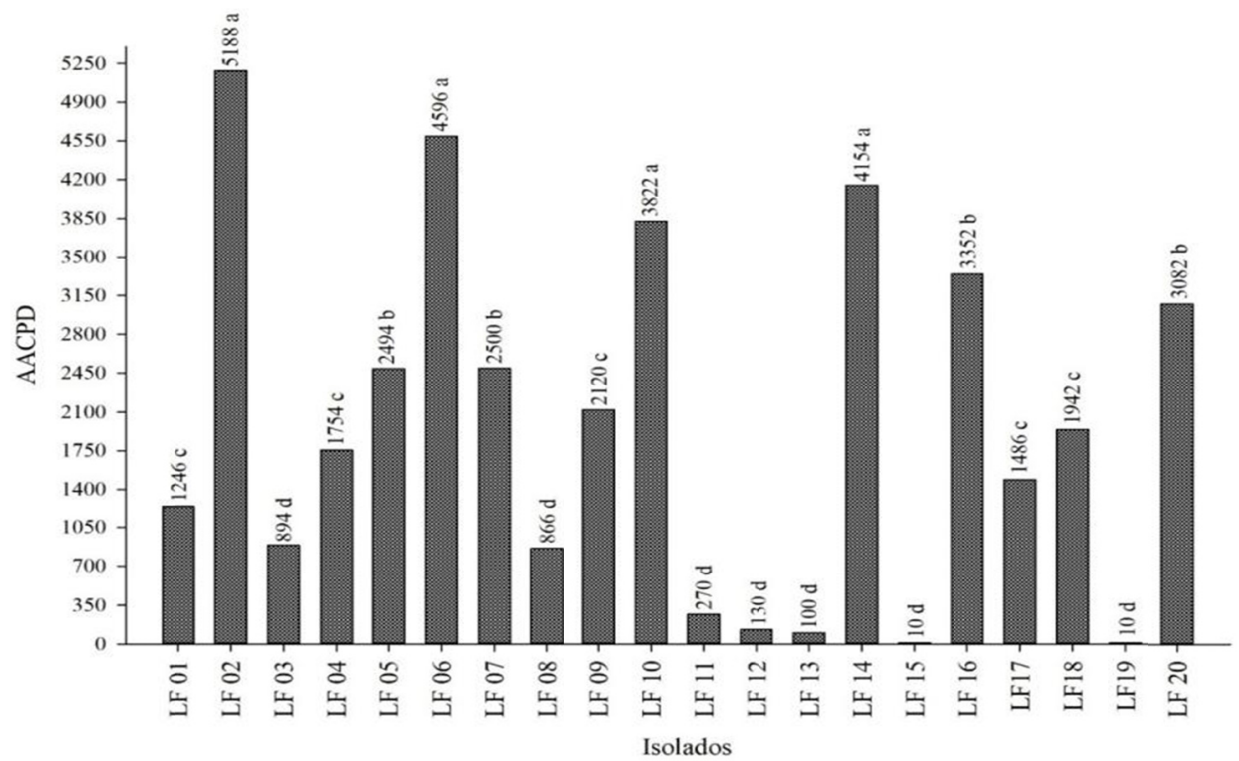

Figure 8. Area Beneath the Disease Progression Curve (AACPD) of 20 isolates inoculated in soybean by the detached leaf method. Frederico Westphalen, RS, 2018 
The different levels of aggressiveness observed in the detached leaf test may be related to the production capacity of oxalic acid or to the amount of enzymes that degrade the host cell wall (Lumsden, 1979; Bolton, 2006), thus presenting four levels different from aggressiveness.

The evaluated populations presented wide variability for the morphological and aggressive characteristics, but it was not possible to analyze the existence of common groups that could be related to the origin of the isolates, due to the high genetic diversity observed.

\section{Conclusions}

The evaluated populations presented wide variability for the morphological characteristics, being prepominate in the colonies myeloic drainage and beige coloration. Also, $60 \%$ of the sclerotia of the isolates were regular near the margin of the plates and with diverse formats.

The isolates presented different levels of aggressiveness, with the most aggressive being LF02 (Bagé City, soybean culture), LF06 (Cristal City, soybean culture), LF14 (Santa Maria Town, lettuce culture) and LF10 (City Palmeira das Missões, soybean culture).

\section{References}

Abreu, G. S., \& Grogn, R. G. (2011). Epidemiology of diseases caused by Sclerotinia species. Phytopathology, 69(8), 899-903.

Akai, J. (1981). Studies on the epidemiology and control of Sclerotinia disease of beans caused by Sclerotinia sclerotiorum (Lib.) de Bary. Hokkaido Prefectural Agr. Exp. Stn. Reotr., 36, 77-79.

Bolton, M. D., Thomma, B. P. H. J., \& Nelson, B. D. (2006). Sclerotinia sclerotiorum (Lib.) DE Bary: biology and molecular traits of a cosmopolitan pathogen. Molecular Plant Pathology, 1(7), 1-16. https://doi.org/ 10.1111/j.1364-3703.2005.00316.x

Bueno, C. J., Ambrosio, M. M. Q., \& Souza, N. L. (2006). Preservation of phytopathogenic fungi living in the soil. Summa Phytopathology, 32(1), 42-50. https://doi.org/10.1590/S0100-54052006000100006

Chaves, G. M. (1961). Studies on Sclerotinia sclerotiorum (Lib) de Bary (79f. Dissertation, Master's Degree. Federal University of Viçosa, Viçosa).

Corradini, H. T. (1989). Characterization in pure culture and pathogenicity of Barry's (Sclerotinia sclerotiorum) (Lib.) Isolates, associated with soybean (Glycine $\max (L$.$) Merrill) in the Alto Paranaiba-MG region$ (Dissertation, Master'S Degree, School of Agriculture of Lavras, Lavras, Brazil).

Demant, C. R. R. (2010). White mold and its management in western Bahia. Bulletin of the Soja, 2(2), 32.

Dickson. (1930). Studies on Sclerotinia sclerotiorum (LIB) de Barry (p. 91). Cornell Univ., Ithaca-NY.

Ekins, M., Hayden, H., Aitken, E., \& Goulter, K. (2011). Populations structure of Sclerotinia sclerotiorum on sunflower in Australia. Australasian Plant Pathology, 40, 99-108. https://doi.org/10.1007/s13313-0100018-6

Fehr, W. R., \& Caviness, C. E. (1977). Stages of soybean development (p. 12). Ames: Iowa State University.

Ferreira, D. F. (2000). Statistical analysis through Sisvar for Windows version 4.0 (pp. 255-258). Annual Meeting of the Brazilian Region of the International Society of Biometry.

Garcia, R. A. (2008). Inoculum production, effects of plant extracts and fungicides, and the reaction of soybean genotypes to Sclerotinia sclerotiorum $(\mathrm{PhD}$ in Phytopathology, Federal University of Uberlândia, Uberlândia).

Grabicoski, E. M. G. (2012). Morphological and pathogenic characterization of isolates of Sclerotinia sclerotiorum (Lib.) From Bary and detection in soybean seeds (Dissertation, Masters in Agronomy, Area of Concentration-Phytopathology, State University of Ponta Grossa, Ponta Grossa).

Juliatti, F. C., \& Juliatti, F. C. (2010). White stem rot of soybean: Management and use of fungicides in search of sustainability in production systems (p. 33). Uberlândia: Composer.

Juliatti, F. C., Santos, J. B., Pozza, E., \& Vieira, R. (2015). Sclerotinia sclerotiorum and White mold: Basic and applied studies. Retrieved from https://www.researchgate.net/publication/299484987

Kreyci, P. F. (2016). Sclerotinia sclerotiorum: Morphological characteristics, aggressiveness, in vitro sensitivity to fungicides and resistance of isolates to methyl thiophanate (Thesis (Doctorate), Luiz de Queiroz School of Agriculture, ESALQ, Piracicaba). 
Kohli, D. K., \& Bachhawat, A. K. (2003). CLOURE: Clustal Output Reformatter, a program for reformatting ClustalX/ClustalW outputs for SNP analysis and molecular systematics. Nucleic Acids Research, 31(13), 3501-3502. https://doi.org/10.1093/nar/gkg502

Kohli, Y., Brunner, L., Yoell, H., Milgroom, M., Anderson, J., Morrall, R., \& Kohn, L. (1955). Clonal dispersal and spatital mixing in populations of the plant pathogenic fungus, Sclerotionia sclerotiorum. Molecular Ecology, 4, 69-77. https://doi.org/10.1111/j.1365-294X.1995.tb00193.x

Kull, L. S., Pedersen, W. L., Palmquist, D., \& Hartman, G. L. (2004). Mycelial compatibility grouping dan aggressiveness of Sclerotionia sclerotiorum. Plant Disease, 88, 325-332. https://doi.org/10.1094/PDIS.2004. 88.4.325

Lehner, M. S., Paula Junior, T. J., Hora Junior, B. T., Teixeira, H., Vieira, R. F., Carneiro, J. E. S., \& Mizubuti, E. S. G. (2015). Low genetic variability in Sclerotinia sclerotiorum populations from common bean fields in Minas Gerais State, Brazil, at regional, local and micro scales. Plant Pathology, 64, 921-931. https://doi.org/10.1111/ppa.12322

Lumsden, R. D. (1979). Histology and physiology of pathogenesis in plan diseases caused by Sclerotinia species. Phytopathology, 69, 890-896. https://doi.org/10.1094/Phyto-69-890

Marciano, P., Di Lenna, P., \& Magro, P. (1983). Oxalic acid, cel wall-degrading enzymes and pH in pathogenesis and their significance in the virulence of two Sclerotinia sclerotiorum isolates on sunflower. Physiological Plant Pathology, 22, 339-345. https://doi.org/10.1016/S0048-4059(83)81021-2

Leite, R. M. V. B. C. (2005). Occurrence of diseases caused by Scleriotinia sclerotiorum in sunflower and soybean (p. 3). Londrina: Embrapa soybean, Technical Communiqué.

Morral, R. A. A., Duczek, L., \& Sheard, J. W. (1972). Variations and correlations within morphology, pathogenicity, and pectolytic enzyme activity in Sclerotinia from Saskatchewan. Canadian Journal Botany, 50(10), 767-85. https://doi.org/10.1139/b72-095

Oliveira, J. A. (1991). Effect of fungicide treatment on seeds in control of cucumber seedlings (Cucumis sativus L.) and pepper (Capsicum annum L.) (Dissertation, (MSc in Phytosanitary), Federal University of Lavras, Lavras-MG).

Pariuad, B., Ravigné, V., Halkett, F., Goyeau, H., Carlier, J., \& Lannou, C. (2009). Aggressiveness anda its role in the adaptation of plant pathogens. Plant Pathology, 58, 409-424. https://doi.org/10.1111/j.1365-3059. 2009.02039.x

Purdy, L. H. (1955). A broader concepto f the species Sclerotinia sclerotiorum based on variability. Phytopathology, 45, 421-427.

Reis, E. M., \& Tomazini, S. L. (2005). Viability of Sclerotinia sclerotiorum sclerotia at two depths in soil. Summa Phytopathologica, 31, 97-99.

Saharan, G. S., \& Mehta. (2008). Sclerotinia Diseases of Crop Plants: Biology, Ecology and Desease Management. India: Springer. https://doi.org/10.1007/978-1-4020-8408-9

Shaner, G., \& Finney, R. E. (1977). The effects of nitrogen fetilization on the expression of slow-mildwing in Knox wheat. Phytopathology, 67, 1051-1055. https://doi.org/10.1094/Phyto-67-1051

Silva, L. H. C. P., Campos, H. D., \& Silva, J. R. C. (2010). Management of soybean white mold. In L. H. C. P. Silva, H. D. Campos, \& J. R. C. Silva (Eds.), Phytosanitary management of agroenergy crops (pp. 205-214). Lavras: UFLA.

Townsend, B. B., \& Willetts, H. J. (1954). The development of sclerotia in certain fungi. Transactions of the British Mycological Society, 37, 213-221. https://doi.org/10.1016/S0007-1536(54)80003-9

Willets, H. J., \& Wong, J. A. (1980). The biology of Sclerotinia sclerotiorum, S. trifoliorum and S. minor with emphasis on specific nomenclature. Botanical Review, 46, 101-165. https://doi.org/10.1007/BF02860868

\section{Copyrights}

Copyright for this article is retained by the author(s), with first publication rights granted to the journal.

This is an open-access article distributed under the terms and conditions of the Creative Commons Attribution license (http://creativecommons.org/licenses/by/4.0/). 